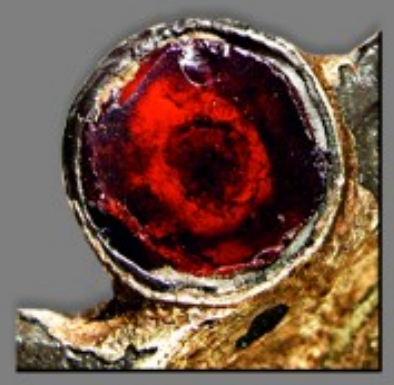

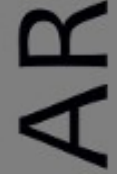

$\sim$

ш
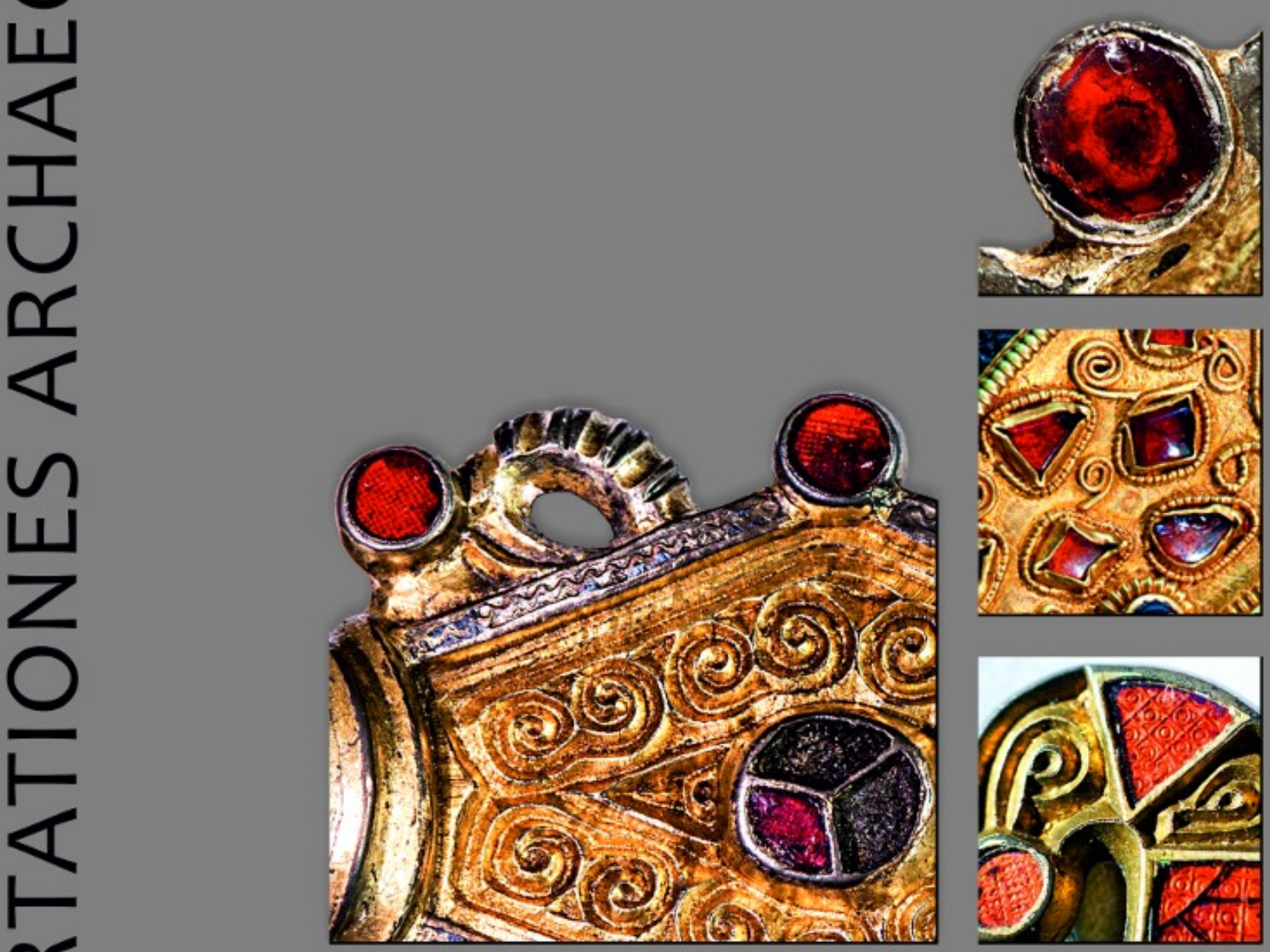

E

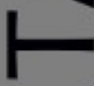

œ

山

n

ก

$\overline{0}$
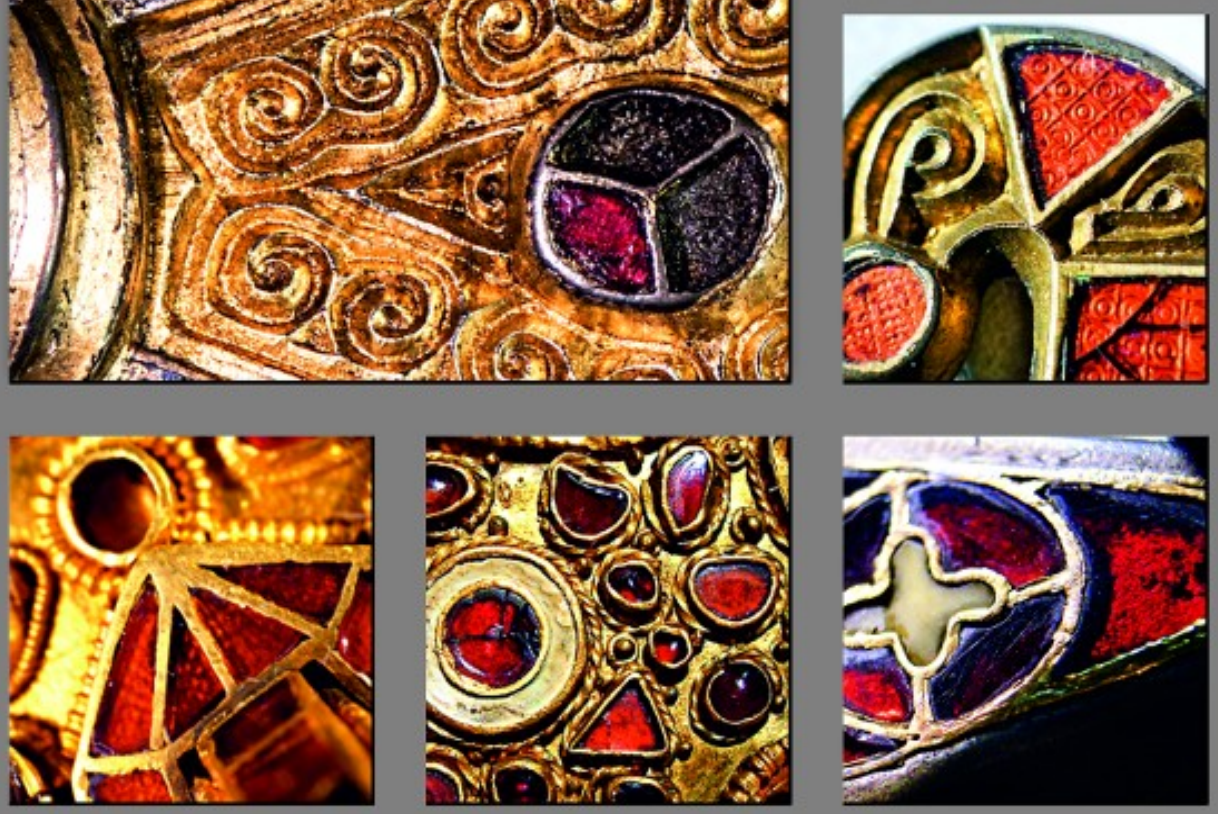

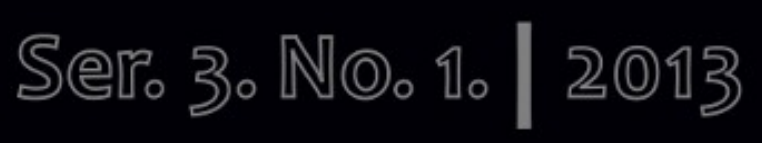




\section{Dissertationes Archaeologicae ex Instituto Archaeologico}

Universitatis de Rolando Eötvös nominatae Ser. 3. No. 1.

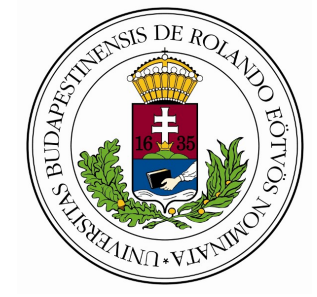

Budapest 2013 
Dissertationes Archaeologicae ex Instituto Archaeologico

Universitatis de Rolando Eötvös nominatae

Ser. 3. No. 1.

Editor-in-chief:

DÁvid BARTUS

Editorial board:

LÁSZLÓ BARTOSIEWICZ

LÁSZLÓ BORHY

ISTVÁN FELD

GÁBOR KALLA

PÁL RACZKY

Miklós SzABÓ

TIVADAR VIDA

Technical editors:

DÁvid BARTuS

GÁBOR VÁCZI

ANDRÁs BöDŐcs

Proofreading:

Zsófia KondÉ

SzILvia SzÖLlősI

Available online at http://dissarch.elte.hu

Contact: dissarch@btk.elte.hu

\section{$\underline{\text { PKP }}$ \\ PUBLIC \\ KNOWLEDGE \\ PROJECT}

(C) Eötvös Loránd University, Institute of Archaeological Sciences

Budapest 2013 


\section{Contents}

\section{Articles}

Melinda TORBÁGYI - István VIDA

The coin hoard of Abasár

Anikó BózsA

21

Roman mirrors from a private collection in the Hungarian National Museum

Lajos JuHÁsz

45

The Biesheim cameo - a reinterpretation

\section{Methods}

Péter CsIPpÁN

$A z$ állatcsont, mint információhordozó leletanyag

Kata DÉvAI

Terminológiai alapfogalmak régészeti korú üvegtárgyak elemzéséhez

Lőrinc TimáR - Zoltán Czajlik - Sándor Puszta - Balázs Holl

$3 D$ reconstructions using GPR data at the Mont Beuvray

\section{FIELD REPORTS}

Zsolt MESTER

Excavation at a new Upper Palaeolithic site of the Eger region (Northern Hungary)

László BORHY - Dávid BARTus - Emese SzÁmadó

Short report on the excavations at Brigetio (Szőny-Vásártér) in 2013

Dénes HulLÁm - Zsófia RÁcz

Report on the participation of the Eötvös Loránd University at the Wielbark Archaeological Field School in Malbork-Wielbark, Poland

Gábor VÁczi - Dávid BARTus

Short report on the excavations at the site Makó - Igási Ugar

Maxim MoRdovin

Short report on the excavations in 2013 of the Department of Hungarian Medieval and Early Modern Archaeology (Eötvös Loránd University, Budapest)

\section{THESIS ABSTRACTS}

Kitti KÖHLER

Biological reconstruction of the Late Neolithic Lengyel Culture 
Cultural connections and interactions of Eastern Transdanubia during the Urnfield period

Orsolya LÁNG

Urban problems in the civil town of Aquincum: the so-called „northern band”

Nikoletta SEY

Questions of bronze workshops in Roman Pannonia

Kata DÉvaI

Glass vessels from Late Roman times found in graves in the Hungarian part of Pannonia

Eszter HORvÁTH

Gemstone and glass inlaid fine metalwork from the Carpathian Basin:

the Hunnic and Early Merovingian Periods

Gergely SzEnTHE

Vegetal ornaments in the Late Avar decorative art

Péter LANGó

Relations between the Carpathian Basin and South East Europe during the 10th century.

The evidence of the minor objects

Ciprián HoRvÁTH

The Cemeteries and Grave Finds of Györ and Moson Counties from the Time

of the Hungarian Conquest and the Early Árpádian Age

András Sófalvi

The border- and self-defence of Szeklers from the Medieval Age till the Age of Principality.

Castles and other defence objects in the settlement history of Udvarhelyszék 


\title{
Short report on the excavations at the site Makó - Igási Ugar
}

\author{
GÁBOR VÁCZI \\ Institute of Archaeological Sciences \\ Eötvös Loránd University \\ vaczigabor@gmail.com
}

DÁvid BARTUS

Institute of Archaeological Sciences

Eötvös Loránd University

bartusdavid@gmail.com

\begin{abstract}
The Institute of Archaeological Sciences, Eötvös Loránd University carried out preventive excavations at the site Makó - Igási Ugar in the frame of the highway construction works of section "M43 Makó - Csanádpalota" in 2012-2013, where traces of a settlement from the 12th century were found.
\end{abstract}

\section{The site}

Makó (Csongrád county) is situated in the south-eastern part of Hungary, near the Romani an border (Fig. 1). The site "Igási Ugar" was identified during the fieldwalking campaigns of the Hungarian National Museum - National Heritage Protection Centre, preceding the construction works of highway section M43 "Makó - Csanádpalota". During the fieldwalking numerous pottery sherds from the Árpádian Age were found, which indicated a settlement. Unfortunately, the route of the highway covered only the northern - as later was recognized, less intensive - part of the site.

The Institute of Archaeological Sciences ${ }^{1}$ started the excavation at the beginning of November 2012 by digging two 4 metres wide and 100 metres long test trenches, where numerous archaeological features were visible in a depth of $60-70 \mathrm{~cm}$. The site was also examined by metal detector; bronze mounts, rings, sickles and a copper coin of King Béla III were found. After the enlargement of the excavation surface and the removal of the upper humus layer, more than one hundred archaeological features (mainly pits and trenches) were identified in a territory of one hectare. After a winter break and an extraordinary cold and wet March, the excavation was finished at the beginning of May, with a total of 118 features unearthed.

\section{Settlement structure}

As mentioned above, only the northest periphery of the settlement could be excavated, therefore comprehensive observations on the settlement structure cannot be made yet. Several 1-1.5 $\mathrm{m}$ wide and 1-1.8 $\mathrm{m}$ deep trenches in the direction of north-south were found in the whole territory of the excavation, at a distance of 55-60 metres from each other (Fig. 1-2). The outermost trenches indicate the western and eastern border of the settlement. Although some smaller trenches oriented perpendicularly to the larger ones creating a grid-like structure were also found, traces of buildings apart from some isolated rows of postholes could not be identified.

1 The excavation was directed by Gábor Váczi, assistant research fellow (Eötvös Loránd University). Participants were Dávid Bartus PhD, senior lecturer and András Füzesi (Eötvös Loránd University). 
The largest pit of the excavation with a diameter of 8-9 $\mathrm{m}$ can be interpreted as a well. Unfortunately, in a depth of 4-4.5 m the wall of the shaft started to collapse due to a loose sand layer and the continuous inrush of water, therefore unearthing the well could not be finished. However, some observations could be made on the structure of the well; its shaft is rectangular, measuring $1.5 \times 1.5 \mathrm{~m}$, the pit used for the construction is circular with a diameter of 4 metres. According to the finds, the well can be dated to the Árpádian Age. Beside the trenches and pits, the relatively large number of ovens should be mentioned, some of which were repeatedly renewed (Fig. 3). Most of them also had working pits with slightly abundant find material.

\section{Find material}

The overall density of finds was low in the whole excavated area of the site, which can be explained by the above-mentioned observations on the presumed structure of the settlement. Most of the find material came from the working pits and foundation layers of ovens, while the pits and trenches - especially on the border of the site - have only a few potsherds and animal bones. The most representative pottery type from the site is the cauldron, of which a relatively large quantity were found (Fig. 4). Beside pottery and animal bones, only some worked stones, bronze sheets and iron slags were found, which also strengthen the observation that the central, more dense and intensively populated part of the 12th century settlement at Makó - Igási Ugar was situated southwards from our excavation. 


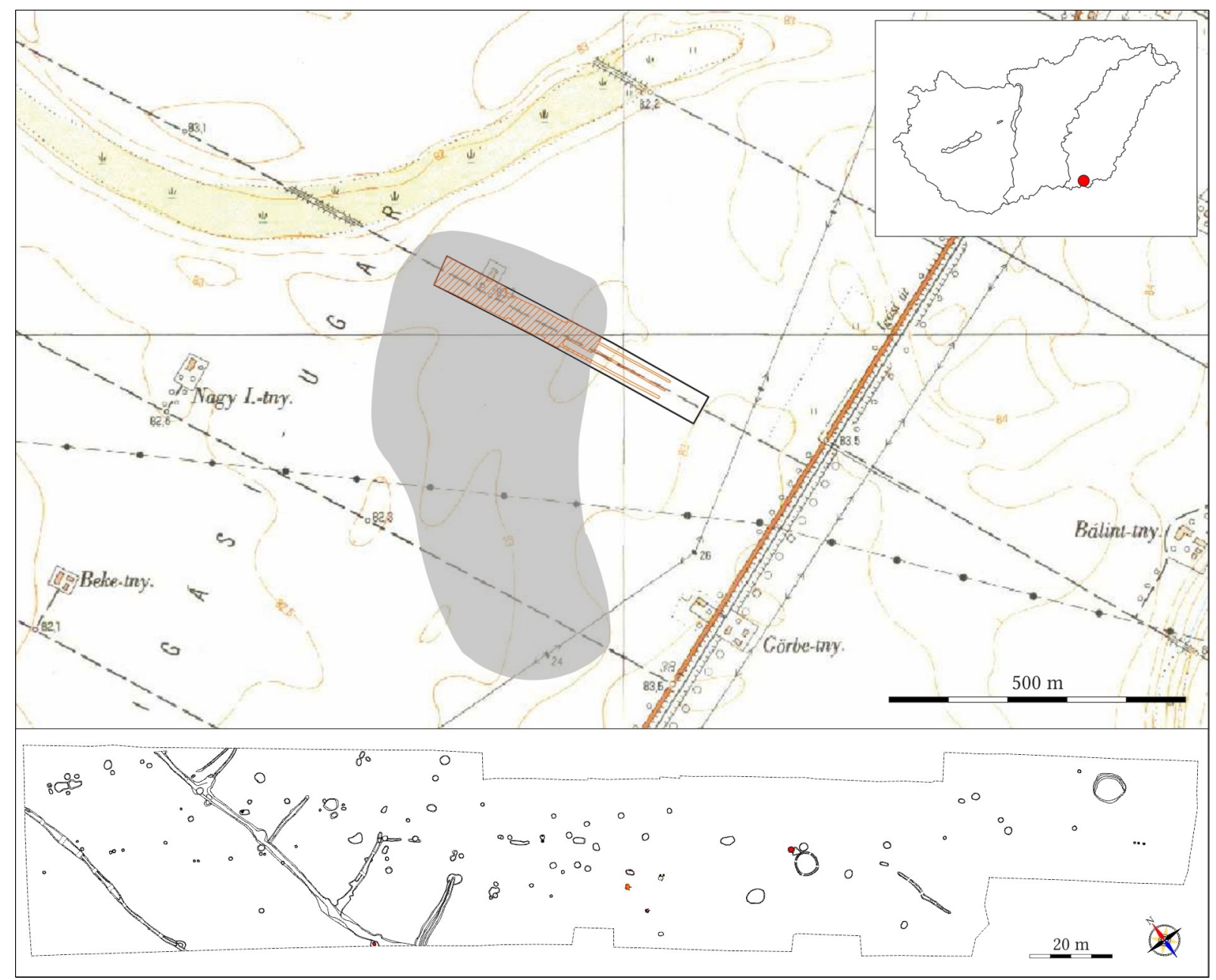

Fig. 1. Plan of the excavation (G. Váczi).

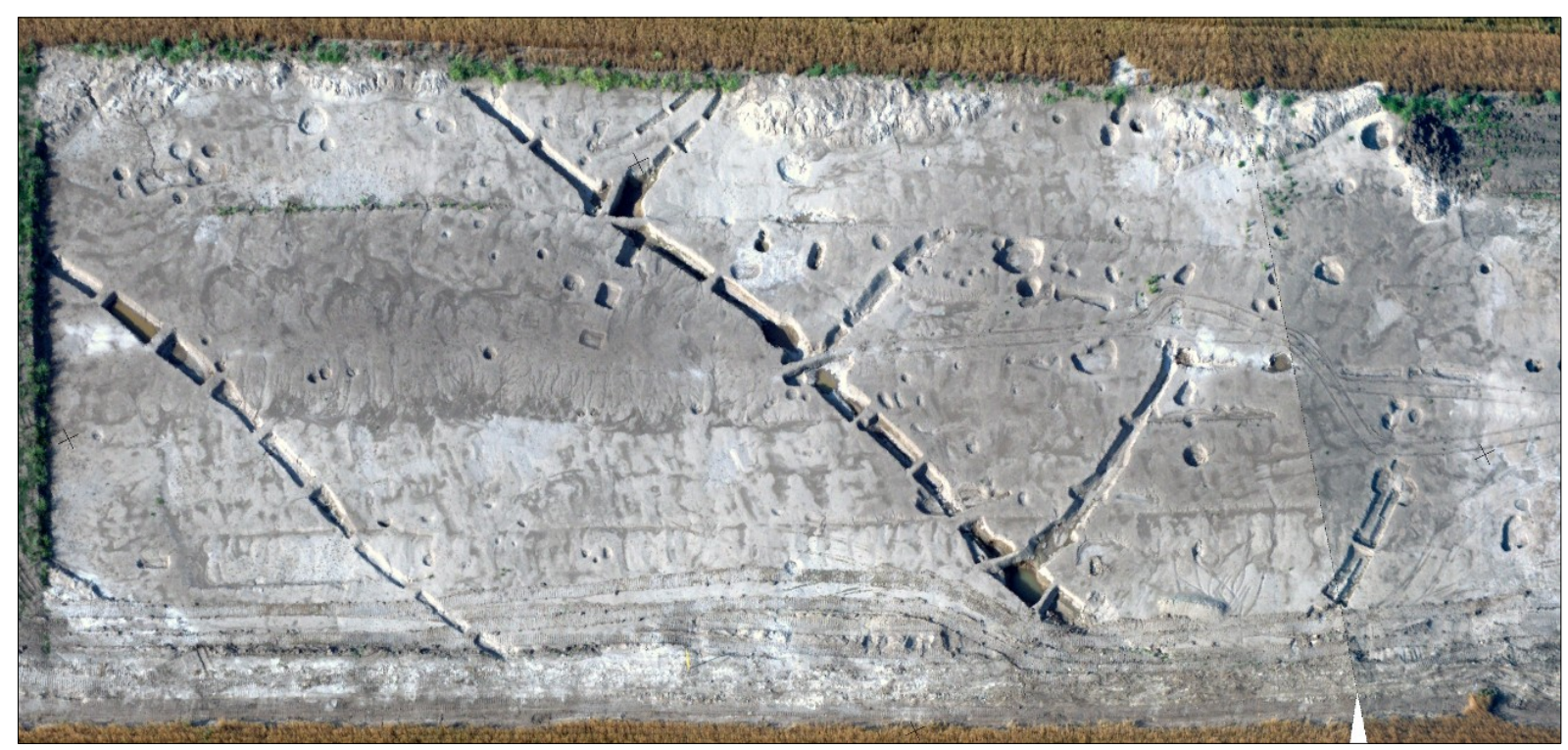

Fig. 2. Aerial photo of the northwestern part of the excavation (Photo: Z. Czajlik). 


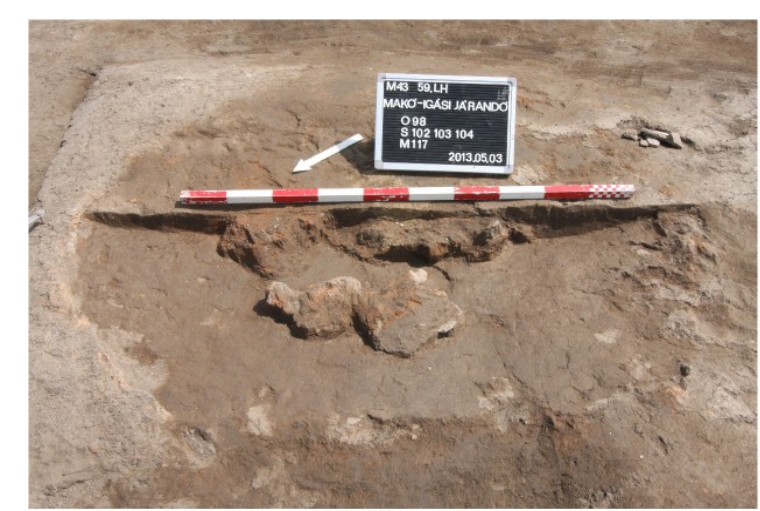

1

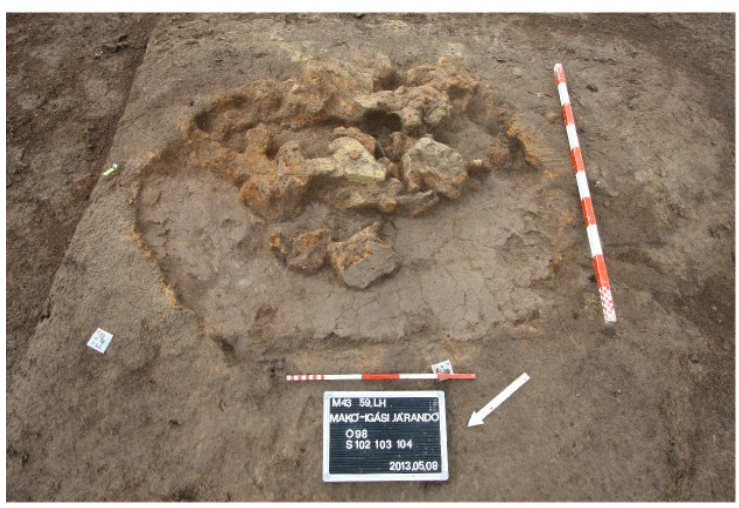

2

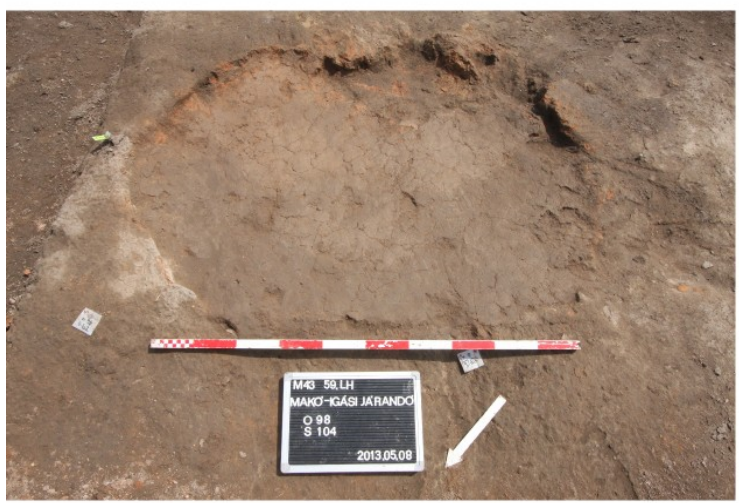

3

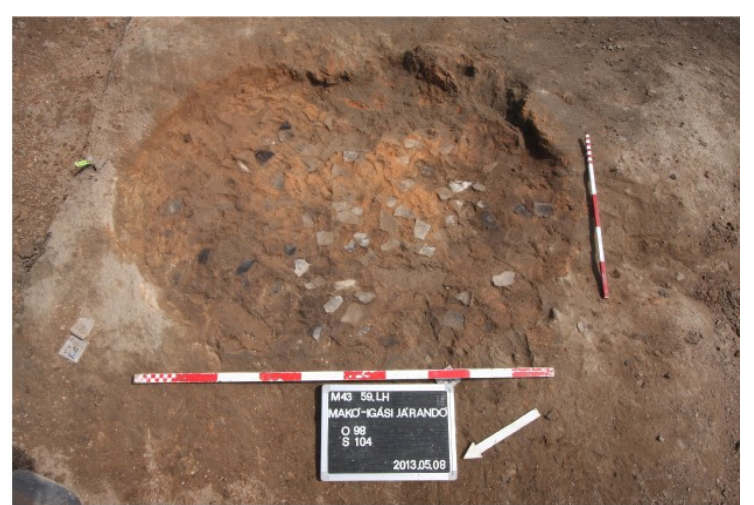

4

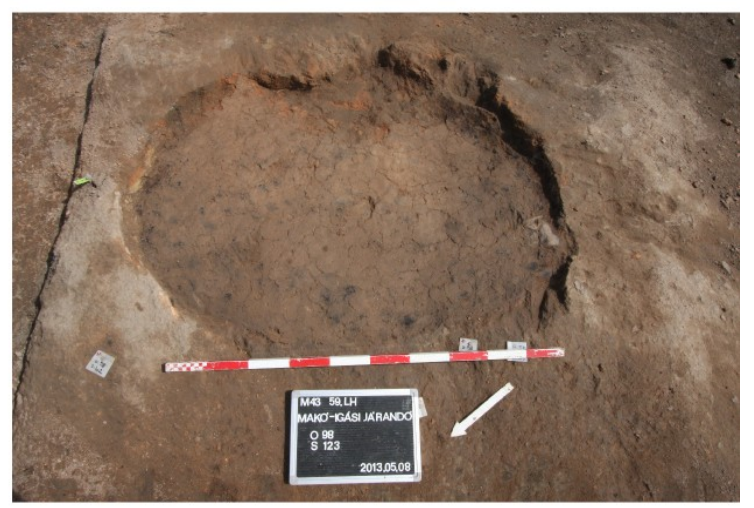

5

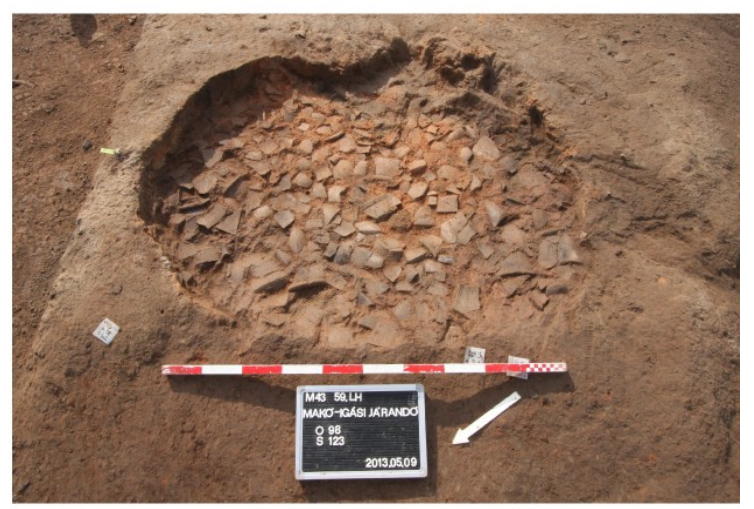

6

Fig. 3. Remains of the vault and multiple foundation layers of an oven (Photos: D. Bartus). 


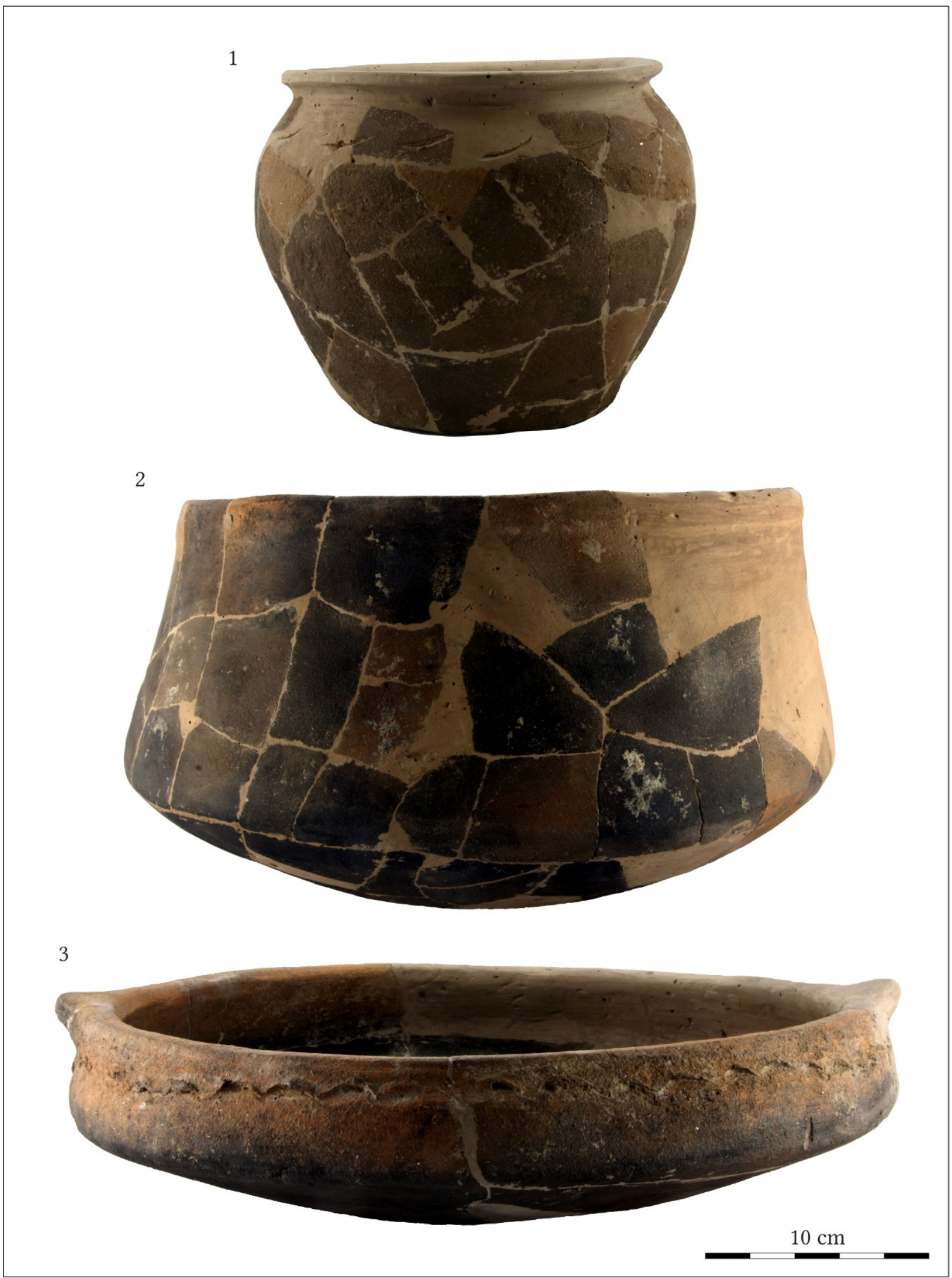

Fig. 4. Pottery from the site (Photos: D. Bartus). 